\title{
Experimental Study and Analysis of Condenser Performance under Dual Backpressure Operation Mode
}

\author{
Guangyao Liu", ${ }^{1, a}$, Xiewei Cheng ${ }^{2, b}$, Xuedong Wang ${ }^{3, c}$ \\ ${ }^{1}$ Huadian Electric Power Research Institute, Hangzhou ,P.R. China \\ ${ }^{2}$ Safety production part of Shandong Branch Company of Huadian Power International Ltd. Co., \\ Jinan, P.R.China \\ ${ }^{3}$ Shandong Branch of Huadian Electric Power Research Institute, Jinan ,P.R. China

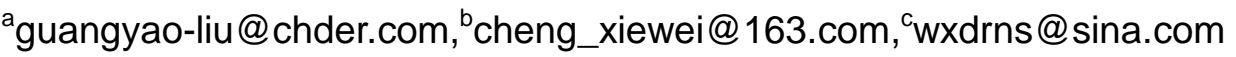

Keywords: steam turbine unit, condenser modification, high backpressure modification, dual backpressure operation, cooling water heat supply.

\begin{abstract}
The condenser modification of a 150MW unit for high backpressure cooling water heat supply is introduced in this paper. Economy characteristics of the transformed condenser are calculated using the high and low backpressure operation data. The condenser terminal difference is $2.354^{\circ} \mathrm{C}$ under high backpressure condition, which is lower than the design value $\left(4^{\circ} \mathrm{C}\right)$. The condenser terminal differences under three low backpressure conditions are $6.535^{\circ} \mathrm{C}, 5.358^{\circ} \mathrm{C}$ and $5.148^{\circ} \mathrm{C}$ respectively, and the corrected values of it by inlet water flow and temperature are $8.721^{\circ} \mathrm{C}, 7.179^{\circ} \mathrm{C}$ and $6.724^{\circ} \mathrm{C}$, all of which are higher than the design value $\left(4^{\circ} \mathrm{C}\right)$ and those before modification. The total condenser heat-transfer coefficient is $2.183 \mathrm{~kW} /\left(\mathrm{m}^{2}{ }^{\circ} \mathrm{C}\right)$, lower than the mean value before modification which is $3.388 \mathrm{~kW} /\left(\mathrm{m}^{2}{ }^{\circ} \mathrm{C}\right)$. It is shown that with the condenser modification, the unit safety can be guaranteed during normal operation, yet the economy parameters are poorer than design values, being lower than those before modification. In $125 \mathrm{MW}$ load condition, the condenser back pressure after modification is $0.9 \mathrm{kPa}$ higher than that before modification.
\end{abstract}

\section{Introduction}

In normal condensing thermal power plant, the turbine exhaust steam in the condenser is cooled and condensed into water by circulating water, so the circulating water is heated and the heat emission through the cooling tower into the atmosphere results in a loss of cold source. This kind of loss is one of the main factors causing low cycle thermal efficiency of the steam turbine unit. If this cooling source is used, it will greatly improve the thermal efficiency of the steam turbine. Steam turbine high backpressure circulating water heat-supply technology is therefore developed by taking advantage of the steam turbine cold source to save energy and to protect the environment. The condenser circulating water outlet temperature increases because the steam turbine exhaust temperature rises when condenser operates in high back pressure mode. The user heating demand can be satisfied by connecting the condenser circulating water inlet pipe and the outlet pipe with heat supply system. The circulating water heated by the condenser is pumped into heat supply network, and then returns to the condenser to be reheated. High backpressure circulating water heat-supply technology utilizes the heat that is formerly released into the atmosphere, therefore saving heating steam and improving the steam turbine economy performance.

Nowadays, the condenser high backpressure circulating water heat-supply technology for condensing power units has been widely used in domestic cities in winter, which is an effective measure to save energy, to improve the environment and to promote cogeneration[1,2,3,4]. With the 
great change in the low pressure cylinder exhaust steam temperature and in the steam side and water side pressure of the condenser, the long-term safety of the condenser can no longer be guaranteed[5]. Therefore, overall strength transformation of the condenser must be implemented to ensure safety under high backpressure conditions.

\section{The Condenser Modification Content and the Technical Specification after Modification}

Condenser modification content. The 150MW heat supply unit is a super-high-pressure double-extraction condense turbine. The heat supply extraction steam is extracted from the connection tube between the medium- pressure cylinder and the low-pressure cylinder, and the rated heat supply extraction steam flow is $210 t / h$ under the design condition. In response to the increase of heat supply load, a high backpressure heat supply modification is made to the low pressure cylinder; that is, the original $2 \times 6$ stages low pressure rotor is changed into a $2 \times 5$ stages low pressure rotor and the last 3 stages low pressure baffle plate and moving blades are removed. The unit operates under high backpressure condition in heating seasons using the circulating water for heat supply to cope with inadequate heating. In non- heating seasons the high backpressure baffle plates and blades are replaced by the original 3 sets of stationary blades and moving blades, so the low pressure cylinder recovers its original operation state. The low pressure cylinder running state and backpressure value are restored.

In the high backpressure condition, concerning the higher exhaust steam temperature and pressure of the low-pressure cylinder, and the enormous changes in the condenser operation condition (from normal backpressure to high backpressure condition), overall strengthening modification is made to the condenser as follows: water chambers are redesigned, with arc water boxes employed; also redesigned the cooling tube bundle, tube plates, and support plates.; a single-shell condenser is used; double process of the circulating water with double inlet and double outlet is adopted; the condenser and the steam turbine exhaust hood are connected by stainless steel expansion joints, and the vertical thermal expansion of the condenser is compensated by the expansion joint; in order to ensure the tight sealing of the condenser circulating water pipe and tube plate, the condenser tube plate and tube hole are slotted in tube hole, and the circulating water tube and tube plate are connected by slotted expansion joint; Q345R steel plate with proper thickness is used for the condenser tube plate.

The condenser technical specification after modification. The condenser technical specification after modification is listed in Table 1. 
Table 1. The condenser technical specification after modification

\begin{tabular}{|c|c|c|c|}
\hline Type & Shell and tube & Cleanliness factor & 0.85 \\
\hline Model Number & $\begin{array}{l}\mathrm{N}-8900 \text { single shell } \\
\text { and double process } \\
\text { (enhanced) }\end{array}$ & $\begin{array}{l}\text { Design water inlet } \\
\text { temperature }\end{array}$ & $\begin{array}{c}20{ }^{\circ} \mathrm{C} \\
\text { (heating period } 58^{\circ} \mathrm{C} \text { ) }\end{array}$ \\
\hline Shell design pressure & $0.1 \mathrm{MPa}$ & $\begin{array}{l}\text { Maximum water } \\
\text { inlet temperature }\end{array}$ & $\begin{array}{c}33{ }^{\circ} \mathrm{C} \\
\text { (heating period } 65^{\circ} \mathrm{C} \text { ) }\end{array}$ \\
\hline Tube side design pressure & $1.2 \mathrm{MPa}$ & $\begin{array}{l}\text { Circulating water } \\
\text { temperature rise }\end{array}$ & $\begin{array}{c}<8.5^{\circ} \mathrm{C} \text { (non } \\
\text { condenser terminal } \\
\text { difference) }\end{array}$ \\
\hline Heat transfer area & $8900 \mathrm{~m}^{2}$ & $\begin{array}{l}\text { Pipe total water } \\
\text { resistance }\end{array}$ & $\leq 50 \mathrm{kPa}$ \\
\hline Circulating water flow & $\begin{array}{l}19650 \mathrm{t} / \mathrm{h} \\
\text { (heating period } \\
8400 \mathrm{t} / \mathrm{h} \text { ) }\end{array}$ & $\begin{array}{l}\text { Condenser terminal } \\
\text { difference }\end{array}$ & $\leq 6.5^{\circ} \mathrm{C}$ \\
\hline $\begin{array}{l}\text { Circulating water flow rate } \\
\text { in pipe }\end{array}$ & $\begin{array}{c}2 \mathrm{~m} / \mathrm{s} \\
\text { (heating period } \\
0.85 \mathrm{~m} / \mathrm{s} \text { ) }\end{array}$ & $\begin{array}{l}\text { Condensate water } \\
\text { super-cooling } \\
\text { degree }\end{array}$ & $\begin{array}{l}\leq 0.5^{\circ} \mathrm{C} \\
\text { (Maximum guarantee } \\
\text { load condition) }\end{array}$ \\
\hline Steam turbine pressure & $\begin{array}{c}5.4 \mathrm{kPa} \\
\text { (heating period } 40 \mathrm{kPa} \text { ) }\end{array}$ & & \\
\hline \multicolumn{4}{|l|}{ Condenser tube specifications: } \\
\hline Main condensation zone & $\begin{array}{c}\text { Material } \\
\text { HSn70-1AB }\end{array}$ & $\begin{array}{l}\text { Amount } \\
12698\end{array}$ & $\begin{array}{c}\text { Tube size }(\Phi \times \delta) \\
25 \mathrm{~mm} \times 1 \mathrm{~mm}\end{array}$ \\
\hline Air cooling zone & $\mathrm{BFe} 30-1-1$ & 720 & $25 \mathrm{~mm} \times 1.5 \mathrm{~mm}$ \\
\hline
\end{tabular}

The design tube side pressure of the condenser is $0.45 \mathrm{MPa}$ before modification. After modification it is increased when the other parameters remain unchanged. In non-heating conditions, the tube side operating pressure remains to be $0.4 \mathrm{MPa}$. The circulating water system is a closed cycle. In non-heating seasons, groundwater and river water are used as circulating water while in heating seasons the return water of a heat supply network serves the purpose.

In the non-heating period, with the low pressure cylinder restoring its pre-modification condition and the unit resuming its pre-modification operation and the exhaust steam flow rate and the exhaust steam enthalpy being the same as those before modification, even after the modification is made, the condenser backpressure value should also be $5.4 \mathrm{kPa}$ (the pre-modification design value) under low backpressure conditions.

\section{High and low Backpressure Experimental Operation Result of the Condenser}

After the high backpressure heating modification of the steam turbine and the condenser, the condenser operates under high backpressure condition in the heating period in winter and operates under low backpressure condition in the non-heating period, so the condenser's operation condition changes greatly. In order to find the condenser running situation and performance in high and low backpressure, experiments are implemented under high backpressure heating condition and low backpressure condensing condition with the low pressure cylinder re-equipped with blades. Condenser performance parameters are calculated in both conditions and are compared with those pre-modification design value and condenser performance parameters, as shown in Table 2 . 
Table 2. Experimental results in high and low backpressure operation of the 150MW unit condenser

\begin{tabular}{|c|c|c|c|c|c|c|c|c|}
\hline \multirow[b]{2}{*}{ name } & \multirow[b]{2}{*}{ unit } & \multicolumn{4}{|c|}{ After modification } & \multicolumn{3}{|c|}{ Before modification } \\
\hline & & $\begin{array}{c}\text { High } \\
\text { backpressure } \\
\text { heating } \\
\text { condition } \\
\end{array}$ & $\begin{array}{c}\text { Low } \\
\text { backpressure } \\
\text { condensing } \\
\text { condition } \\
\end{array}$ & $\begin{array}{c}\text { Low } \\
\text { backpressure } \\
\text { condensing } \\
\text { condition } \\
\end{array}$ & $\begin{array}{c}\text { Low } \\
\text { backpressure } \\
\text { condensing } \\
\text { condition } \\
\end{array}$ & $\begin{array}{c}\text { Condensing } \\
\text { condition }\end{array}$ & $\begin{array}{l}\text { Condensing } \\
\text { condition }\end{array}$ & $\begin{array}{c}\text { Condensing } \\
\text { condition }\end{array}$ \\
\hline Generator power & $\mathrm{kW}$ & 125595 & 150582 & 126170 & 100330 & 150678 & 123007 & 101234 \\
\hline $\begin{array}{l}\text { Condenser exhaust } \\
\text { pressure }\end{array}$ & $\mathrm{kPa}$ & 29.701 & 7.887 & 7.4935 & 6.730 & 8.4765 & 8.582 & 7.7305 \\
\hline $\begin{array}{l}\text { Hotwell outlet water } \\
\text { temperature }\end{array}$ & ${ }^{\circ} \mathrm{C}$ & 69.339 & 40.751 & 39.933 & 38.046 & 43.09 & 43.54 & 41.69 \\
\hline $\begin{array}{l}\text { Condensing pump outlet } \\
\text { water temperature }\end{array}$ & ${ }^{\circ} \mathrm{C}$ & 69.339 & 40.926 & 40.2 & 38.9 & 43.53 & 43.64 & 41.87 \\
\hline Circulating water flow & $\mathrm{t} / \mathrm{h}$ & 8604 & 17454.7 & 17623.4 & 17622.1 & 17404.2 & 17593.1 & 17106.7 \\
\hline Condenser inlet pressure & $\mathrm{MPa}$ & 0.7534 & 0.3088 & 0.2993 & 0.3042 & 0.2799 & 0.2797 & 0.2797 \\
\hline $\begin{array}{l}\text { Inlet circulating water } \\
\text { pressure }\end{array}$ & ${ }^{\circ} \mathrm{C}$ & 52.203 & 24.654 & 26.465 & 26.144 & 29.62 & 31.92 & 31.32 \\
\hline $\begin{array}{l}\text { Condenser outlet } \\
\text { pressure }\end{array}$ & $\mathrm{MPa}$ & 0.6963 & 0.2249 & 0.2246 & 0.2247 & 0.2248 & 0.2247 & 0.2247 \\
\hline $\begin{array}{l}\text { Outlet circulating water } \\
\text { temperature }\end{array}$ & ${ }^{\circ} \mathrm{C}$ & 67.54 & 34.729 & 34.941 & 33.146 & 39.885 & 40.51 & 38.68 \\
\hline Condenser load & $\mathrm{MJ} / \mathrm{h}$ & 551589 & 734553 & 624152 & 515399 & 746774 & 631700 & 526286 \\
\hline $\begin{array}{l}\text { Saturation temperature } \\
\text { corresponding to } \\
\text { condenser pressure }\end{array}$ & ${ }^{\circ} \mathrm{C}$ & 69.894 & 41.264 & 40.299 & 38.294 & 42.636 & 42.873 & 40.886 \\
\hline $\begin{array}{l}\text { Circulating water } \\
\text { temperature rise }\end{array}$ & ${ }^{\circ} \mathrm{C}$ & 15.337 & 10.075 & 8.476 & 7.002 & 10.265 & 8.59 & 7.36 \\
\hline $\begin{array}{l}\text { Condensing water } \\
\text { super-cooling degree }\end{array}$ & ${ }^{\circ} \mathrm{C}$ & 0.555 & 0.513 & 0.366 & 0.248 & -0.454 & -0.667 & -0.804 \\
\hline $\begin{array}{l}\text { Condenser terminal } \\
\text { difference }\end{array}$ & ${ }^{\circ} \mathrm{C}$ & 2.354 & 6.535 & 5.358 & 5.148 & 2.751 & 2.363 & 2.206 \\
\hline $\begin{array}{l}\text { Logarithmic mean } \\
\text { temperature difference }\end{array}$ & ${ }^{\circ} \mathrm{C}$ & 7.604 & 10.80 & 8.936 & 8.154 & 6.605 & 5.601 & 5.017 \\
\hline $\begin{array}{l}\text { Condenser total } \\
\text { experimental heat } \\
\text { transfer coefficient Kt }\end{array}$ & $\begin{array}{l}\mathrm{kW} /\left(\mathrm{m}^{2}\right. \\
\left..{ }^{\mathrm{o}} \mathrm{C}\right)\end{array}$ & 2.264 & 2.123 & 2.180 & 1.973 & 3.529 & 3.520 & 3.274 \\
\hline $\begin{array}{l}\text { Heat transfer tube flow } \\
\text { area }\end{array}$ & $\mathrm{m}^{2}$ & 2.7747 & 2.7747 & 2.7747 & 2.7747 & 2.7764 & 2.7764 & 2.7764 \\
\hline $\begin{array}{l}\text { Circulating water flow } \\
\text { rate }\end{array}$ & $\mathrm{m} / \mathrm{s}$ & 0.867 & 1.755 & 1.770 & 1.771 & 1.752 & 1.7715 & 1.723 \\
\hline $\begin{array}{l}\text { Design circulating water } \\
\text { flow rate }\end{array}$ & $\mathrm{m} / \mathrm{s}$ & 0.846 & 1.974 & 1.974 & 1.974 & 1.974 & 1.974 & 1.974 \\
\hline $\begin{array}{l}\text { Revised overall heat } \\
\text { transfer coefficient by } \\
\text { circulating water flow } \\
\text { and temperature }\end{array}$ & $\begin{array}{c}\mathrm{kW} /\left(\mathrm{m}^{2}\right. \\
\left..{ }^{\mathrm{o}} \mathrm{C}\right)\end{array}$ & 2.236 & 2.162 & 2.183 & 1.98 & 3.495 & 3.4265 & 3.241 \\
\hline $\begin{array}{l}\text { Revised design } \\
\text { temperature rise by } \\
\text { circulating water flow }\end{array}$ & ${ }^{\mathrm{o}} \mathrm{C}$ & 15.709 & 8.949 & 7.602 & 6.279 & 9.092 & 7.691 & 6.407 \\
\hline $\begin{array}{l}\text { Revised condenser } \\
\text { saturation temperature by } \\
\text { the circulating water flow } \\
\text { and temperature }\end{array}$ & ${ }^{\circ} \mathrm{C}$ & 75.628 & 37.670 & 34.781 & 33.003 & 33.794 & 31.651 & 30.257 \\
\hline $\begin{array}{l}\text { Revised condenser } \\
\text { terminal difference by } \\
\text { the circulating water } \\
\text { flow and temperature }\end{array}$ & ${ }^{\circ} \mathrm{C}$ & 1.919 & 8.721 & 7.179 & 6.724 & 4.702 & 3.96 & 3.85 \\
\hline $\begin{array}{l}\text { Revised condenser } \\
\text { pressure by the } \\
\text { circulating water flow } \\
\text { and temperature }\end{array}$ & $\mathrm{kPa}$ & 39.574 & 6.507 & 5.554 & 5.03 & 5.257 & 4.660 & 4.305 \\
\hline
\end{tabular}




\section{Experimental Result Analysis of both high and low Backpressure Operation of the Condenser}

The analysis of the experimental data about high and low backpressure operation and the comparison with the design value show that for the condenser operating under high and low backpressure conditions, the difference between circulating water flow and the design value under corresponding condition is small. So the circulating water flow rate in the circulating water pipe is approximately the same as the design value. The condenser terminal difference under high backpressure condition is $2.354^{\circ} \mathrm{C}$, which is small, and that after the correction of circulating water flow and inlet water temperature is $1.919^{\circ} \mathrm{C}$; under 3 low backpressure conditions, the condenser terminal differences are $6.535^{\circ} \mathrm{C}, 5.358^{\circ} \mathrm{C}$, and $5.148^{\circ} \mathrm{C}$ respectively. After the correction of circulating water flow and inlet water temperature, the condenser terminal differences are $8.721^{\circ} \mathrm{C}$, $7.179^{\circ} \mathrm{C}$ and $6.724^{\circ} \mathrm{C}$ respectively, higher than the condenser design terminal temperature difference $\left(4^{\circ} \mathrm{C}\right)$. The safety requirements for high backpressure operation can be met after the condenser modification, yet in low backpressure operation the condenser terminal difference is higher than both the design value and that before condenser modification, so it can be concluded that in spite of satisfaction to safety requirements, the performance index is not in accordance with the design value, and the economic performance of the low backpressure operation is reduced.

Effect of steam turbine operating condition on the condenser performance. The condenser design backpressure for heating condition is $40 \mathrm{kPa}$, but the experimental value in corresponding condition is $29.701 \mathrm{kPa}$. Analysis on experimental data and the problems found in experimental process indicates that the extraction steam from the joint pipe of the low pressure cylinder can't be stopped due to the low pressure cylinder flow path modification under high backpressure condition. The steam, as a source of peak heating steam for the heat supply network, can't be stopped in the experiment; as a result, the condenser exhaust is reduced and the condenser backpressure is lower than the design value $(40 \mathrm{kPa})$; in addition, the circulating inlet and outlet water temperatures are also lower than the design values. The cold source loss of the turbine is not adequately used, and the power output of the low-pressure cylinder is reduced, and therefore loss of turbine power output results. According to heat supply load, the unit should preferentially supply heat by operating under high backpressure condition in heating period with the circulating water flow and outlet temperature adjusted to the best values. Only when the heating load increases is the extraction steam taken as the secondary source for the heat exchanger of the heating network to further heat the circulating water. The best design running situation of the turbine and condenser can be kept by this kind of operation mode, with the highest heat efficiency of the turbine achieved and the best energy-saving effect made.

When the turbine operates under low backpressure and 150MW condition with circulating water pump operating at high speed, the inlet temperature of circulating water is $24.654^{\circ} \mathrm{C}$ and the condenser backpressure is $7.887 \mathrm{kPa}$. The experimental circulating water flow velocity is close to design value, and the circulating water temperature rises to $10.075^{\circ} \mathrm{C}$. This shows that the circulating water flow satisfies the operation requirements. Yet the condenser heat transfer ability decreases and the turbine backpressure becomes higher due to problems with the condenser device.

Effect of circulating water flow on the condenser performance. Comparison of design data with operation data under high backpressure and low backpressure conditions respectively shows that under high backpressure condition, both the circulating water flow and circulating water flow velocity in the pipe are low, which affects the accuracy of heat transfer calculation model, the calculation result and also the actual condenser heat transfer ability. Therefore, to guarantee the optimum operation conditions of the steam turbine and the condenser, comprehensive consideration should be given to the relation among heating load, circulating water flow and condenser 
backpressure when the turbine and condenser high backpressure modification is planned. The above condenser experiment reveals the following data: under high backpressure conditions, the condenser backpressure is $29.701 \mathrm{kPa}$; the circulating water flow is $8604 \mathrm{t} / \mathrm{h}$; the circulating water velocity inside the heat transfer pipe is $0.867 \mathrm{~m} / \mathrm{s}$; the circulating water flow is larger than the design value; the condenser backpressure and circulating outlet temperature are lower than the design values. This reduces both the condenser high backpressure heating capacity and the unit thermal efficiency. When the unit operates under high backpressure conditions, the extraction steam from the joint pipe of the low-pressure cylinder should be reduced or stopped according to heating load, in order that the circulating water flow and condenser backpressure could be optimized to meet the heating load requirement of high backpressure heating, to improve power generation capacity, and to reduce the circulating water flow and the auxiliary power.

\section{Condenser Performance Comparisons before and after Modification}

After high backpressure heat supply modification, the condenser operates under high backpressure in heating seasons but operates in low backpressure in non-heating seasons, so the low-pressure cylinder steam temperature, the pressure on both the steam side and water side all change greatly. The condenser high back pressure modification can accommodate great changes between two backpressure conditions and optimize the condenser tube bundle layout to improve the condenser performance and yearly running economy of the steam turbine. The comparison of the experimental results under low backpressure condition before and after modification is listed in table 2. After modification of the condenser, the overall average heat transfer coefficient after the correction of the circulating water flow and the temperature is $2.183 \mathrm{~kW} /\left(\mathrm{m} 2{ }^{\circ} \mathrm{C}\right)$, which is smaller than the pre-modification average value $3.388 \mathrm{~kW} / \mathrm{m}^{2}{ }^{\circ} \mathrm{C}$. This indicates that the condenser heat transfer ability after modification is lower than that before modification, which means the relatively poor condenser performance. The revised average terminal temperature difference of the 3 conditions before modification is $4.174^{\circ} \mathrm{C}$, and the revised average terminal temperature difference of the 3 conditions after modification is $7.541^{\circ} \mathrm{C}$. Figure 1 and Figure 2 show how the curves of the condenser pressure and terminal temperature difference change with the unit load.

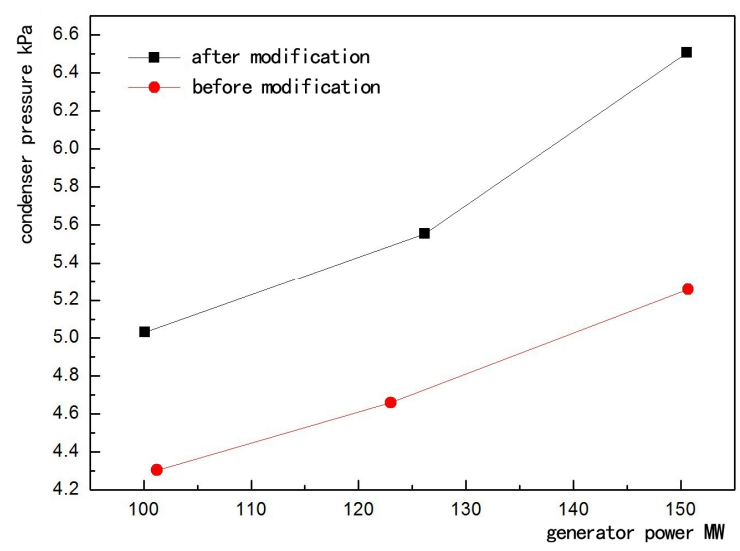

Figure 1. Condenser pressure with the change of power

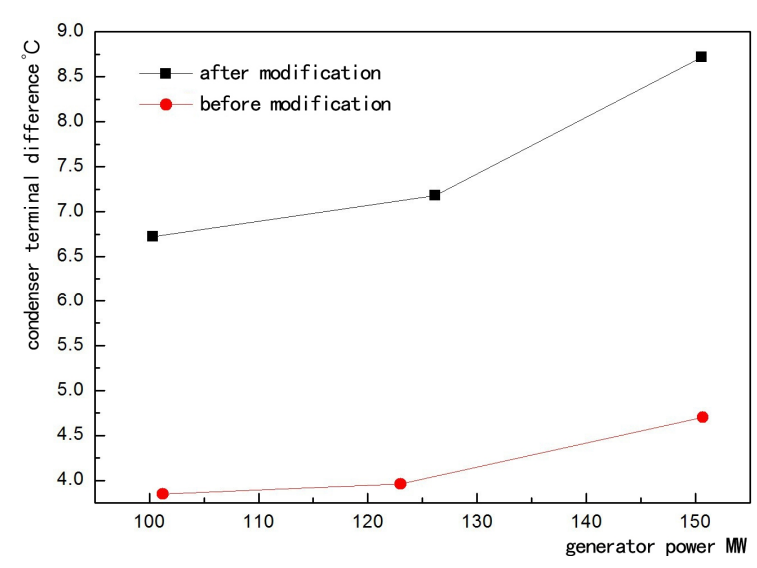

Figure 2. Condenser terminal difference with power

It can be known from the data in Table 2, Figure 1 and Figure 2 that both before and after modification the condenser pressure and terminal temperature difference increase with the growth of unit load, and that the condenser pressure difference and the terminal temperature difference between the values before and after modification increase. Under conditions of average operating load of $125 \mathrm{MW}$, the backpressure rises by nearly $0.9 \mathrm{kPa}$ after modification, which results in the 
power supply coal consumption rising by nearly $2.8 \mathrm{~g} / \mathrm{kWh}$. The inferior performance after the condenser modification illustrates that although safe operation under two backpressure conditions can be achieved, yet without any variation in the heat transfer area, tube arrangement, heat transfer tube material and condenser shell, this modification fails to optimize performance, even aggravates it. The result is the unit economy under low backpressure condition after the condenser modification declines.

Concerning high backpressure unit modification, for the sake of safe operation, the condenser modification is a must. The focus of the design lies in the condenser operation under high backpressure condition. Under high backpressure condition, low circulating water flow and low heat transfer tube circulation flow rate affect accuracy of condenser heat transfer calculation model and that of calculation results, which leads to the degradation of the unit adaptability to the load variation and the unit performance index. The condenser experimental data under low backpressure condition fails to reach the design value, and the performance index is even worse than before. Therefore, with the turbine and the condenser high backpressure modification combined, the condenser performance should be optimized under the promise of both high and low backpressure operational safety; that is, the condenser heat transfer area, the arrangement of the tubes and the condenser operation economy index under low backpressure condition should be optimized to improve the unit economical efficiency and to enhance the year-round operation economy.

\section{Conclusion}

The condenser performance index of two backpressure conditions is calculated according to the experimental data of the high and low backpressure operation situations after the high backpressure heating modification of a $150 \mathrm{MW}$ unit. When the circulating water flow is close to the design value, the condenser terminal difference $\left(2.354^{\circ} \mathrm{C}\right)$ under high backpressure condition is small. The condenser terminal differences under 3 low backpressure conditions are $8.721^{\circ} \mathrm{C}, 7.179^{\circ} \mathrm{C}$, and $6.724^{\circ} \mathrm{C}$ respectively, which are all higher than the normal design value $\left(4^{\circ} \mathrm{C}\right)$ and than that before modification. The overall heat transfer coefficient of $2.183 \mathrm{~kW} /\left(\mathrm{m}^{2}\right)$ is lower than the average value of $3.388 \mathrm{~kW} /\left(\mathrm{m}^{2}\right)$ before modification. Although the condenser performance after high backpressure modification meets perennial safe operation requirements, yet it matches neither the design value nor the condenser performance before modification. This leads to the condenser backpressure under average load $125 \mathrm{MW}$ condition being nearly $0.9 \mathrm{kPa}$ higher than that before modification. With the unit load increasing, the condenser performance index drops even further and the unit economy efficiency of low back pressure operation also declines. For high backpressure reforming turbine, the turbine performance optimization and the turbine and condenser high backpressure modification should be made under the promise of both high and low backpressure operational safety to improve the unit economy efficiency of low back pressure condition and also of the operation all year round.

The heating extraction steam from the joint tube of the low pressure cylinder can't be stopped in the high backpressure experiment process, so the condenser exhaust reduces. As a result, the condenser backpressure is lower than the design value $(40 \mathrm{kPa})$ and the circulating water inlet and outlet temperatures are lower than the design values. The cold source of the steam turbine is not maximally used, leading to lower power output and lower thermal efficiency. During the heating period, priority should be given to the use of high pressure condenser heating. When the heating load increases, the extraction steam can be considered as the secondary steam source for the heat exchanger. This could enable the steam turbine and the condenser to operate in the optimal design state, producing the highest thermal efficiency of the steam turbine and the best energy-saving effect. 


\section{References}

[1] Kao Fang. Analysis of Circulating Water Heat Supply Reformation in an Unit on Low Vacuum of Small Condensing Steam Turbine[J].Shandong Electric Power, 2010,3:46-48.

[2] Fang Min, Cong Lu. Application and economic benefit analysis for the first stage of circulating water heating technology in Yinchuan thermal power plant[J]. Journa 1 of Shenyang Institute of Engineering (Natural Science), 2010,vol6(1):10-12.

[3] Zhang Xiukun, Zheng Gang, Liu Chuanwei,et al. The Analysis and Application of Low Vacuum Circulating Water Heating Technology of Condensate Pumping Unit[J]. Journal of Shanghai University of Electric Power, 2009,vol25(6):543-546.

[4] Zheng Jie. Application of Circulating Water Heat Supply Technology in an Unit on Low Vaccum Running[J]. Energy Conservation Technology, Jul.2006,No.4:380-382.

[5] Dong Xuening, Li Hongchun, Guo Yushuang. Safety Analysis on Turbines Heated by Circulating Water after Retrofit[J].Northeast Electric Power, 2005, 3:5-8. 